\title{
USAHATANI YANG BERKEADILAN GENDER DAN MENGUNTUNGKAN
}

\author{
Elsje Pauline Manginsela
}

\begin{abstract}
This article aims to promote the use of formulas that can provide information on whether a farm not only profitable but also have gender equality. This paper describes the formula and how to apply them, which is based on a review of secondary data collected from various literatures. Issues highlighted in this paper is the measuring instrument to assess whether a farm run by farmers profitable and gender so that it can farm resilience, developing and sustainable? Based on the application of the formula on a farm that is exemplified in this paper it will be concluded whether a farm has a chance to survive in the face of crisis, growing and sustainable.
\end{abstract}

Key words: index, profitable, farming, BG ratio, gender equality

\begin{abstract}
ABSTRAK
Penulisan artikel ini bertujuan mempromosikan penggunaan formula yang dapat memberikan informasi apakah suatu usahatani tidak saja menguntungkan tetapi juga berkeadilan gender. Tulisan ini menjelaskan bentuk formula dan cara bagaimana menerapkannya, yang didasarkan pada kajian data sekunder yang dikumpulkan dari berbagai literatur. Permasalahan yang disoroti dalam tulisan ini belum adanya alat ukur yang dapat memberikan penilaian apakah suatu usahatani yang dijalankan oleh petani menguntungkan dan berkeadilan gender sehingga usahatani tersebut dapat tahan kritis, berkembang dan berkelanjutan? Berdasarkan penerapan formula pada suatu usaha tani yang dicontohkan dalam tulisan ini maka akan dapat disimpulkan apakah suatu usahatani memiliki peluang bertahan kritis dalam menghadapi krisis, berkembang dan berkelanjutan. Kiranya artikel ini dapat memberikan sumbangan bagi penegakan Hak Asasi Manusia dan Demokrasi sehingga tidak ada eksploitasi antara jenis kelamin.
\end{abstract}

Kata kunci: ratio, usahatani, menguntungkan, BG ratio, berkeadilan gender 


\section{PENDAHULUAN}

Sejalan dengan waktu dan kemajuan diberbagai bidang maka usahatani yang mulamula hanya dimaksudkan untuk memenuhi kebutuhan keluarga mulai diarahkan kegiatan yang rasional dan komersil yang menguntungkan. Untuk itu diperlukan berbagai upaya agar usahatani dapat memberikan keuntungan yang optimum.

Beberapa penelitian sebelumnya menunjukkan bahwa terdapat berbagai variasi dalam hal partisipasi wanita dalam pelaksanaan kegiatan usahatani mulai dari lebih dominan, setara dan lebih rendah. Demikian juga dalam hal kesempatan (akses) dan kewenangan (kontrol atau pengambilan keputusan) yang mereka miliki bervariasi. Penelitian Bhastoni dan Yuliati (2016) menunjukkan bahwa wanita lebih berpartisipasi dalam hal pelaksanaan kegiatan usahatani namun kesempatan atau peluang dan wewenang lebih besar berada di pihak pria. Sedangkan penelitian Notoatmojo (2011) menunjukkan bahwa wanita tani sangat berperan sebagai pengelola keuangan dan pembuatan perencanaan dalam melaksanakan dan memutuskan kebijakan dan tugas usaha tani sedangkan pria tani lebih berperan dalam hal pengadaan faktor produksi dan menentukan macam komoditi yang akan diusahakan. Temuan Meiranti (2016), pria dan wanita belum setara pada pola pembagian kerja bahkan kesetaraan gendernya pun masih rendah dalam kegiatan usahatani. Hasil penelitian Rosmawati, La Rianda, dan St. Aida Adha Taridala (2016) menunjukkan bahwa pada pembagian kerja produktif, termasuk dalam kegiatan usahatani keluarga, meskipun suami dan isteri memiliki akses yang sama dalam usaha tani namun suami lebih dominan dibanding isteri. Dalam hal pengambil keputusan dalam usaha tani, suami lebih dominan berperan dibanding isteri. Taridala (2010) menemukan bahwa laki-laki lebih banyak berperan dalam pengelolaan usahatani keluarga.

Berdasarkan beberapa penelitian, dapat ditarik kesimpulan bahwa keuntungan yang cenderung hanya dinikmati sekelompok kecil orang saja maka cepat atau lambat akan merugikan usahatani itu sendiri. Untuk itu, perlu diupayakan keuntungan yang adil bagi semua yang terlibat dalam suatu usaha tani, baik antar pemilik, penggarap dan buruh maupun antara kaum laki-laki dan kaum perempuan karena penelitian Siwi (1997) menunjukkan bahwa peran gender sangat penting dalam upaya pembangunan usaha tani dan peningkatan pendapatan petani. Untuk itu, usahatani yang berkeadilan perlu diupayakan agar tercipta usahatani yang menguntungkan, sehat dan tahan krisis (resiliens), berkembang dan berusia panjang (berkelanjutan).

\section{KONSEP USAHATANI DAN GENDER}

\section{A. Konsep USAHATANI}

Pengertian yang dikemukakan oleh BACHTIAR RIFAI, sejalan dengan yang dikemukakan MOSHER, ialah: setiap organisasi dari alam, tenaga kerja dan modal, yang ditujukan kepada produksi di lapangan pertanian. Ketata laksanaan organisasi itu sendiri diusahakan oleh seorang atau sekumpulan orang-orang. Dengan demikian dari batasan ini dapat diketahui bahwa usahatani terdiri atas manusia petani (bersama keluarganya), tanah (bersama fasilitas yang ada di atasnya seperti bangunan-bangunan, saluran air) dan tanaman ataupun hewan ternak.

Dalam usahatani, tanaman yang diusahakan tidaklah terbatas pada satu macam tanaman tertentu, tetapi dapat terdiri atas berbagai macam tanaman. Begitu pula tanaman yang diusahakannya, ataupun kombinasi antara tanaman, ternak ataupun pemeliharaan ikan.

\section{B. Konsep GENDER}

Pengertian gender mengacu pada suatu sifat yang melekat pada kaum laki-laki maupun perempuan yang dikonstruksi secara sosial maupun kultural. Semua hal yang dapat dipertukarkan antara sifat perempuan dan laki-laki, yang bisa berubah dari waktu ke waktu serta berbeda dari tempat ke tempat lainnya, 
maupun berbeda dari suatu kelas ke kelas yang lainnya, itulah yang dikenal dengan konsep gender.

Terbentuknya perbedaan-perbedaan gender diantaranya dibentuk, disosialisasikan, diperkuat bahkan dikonstruksi secara sosial atau kultural melaluai ajaran keagamaan maupun negara.

\section{DIAGNOSA KEUNTUNGAN USAHATANI YANG BERKEADILAN GENDER}

Agar usahatani dapat memberikan keuntungan maka diperlukan upaya agar dikelola dengan tujuan memperoleh produksi yang maksimum dari semua cabang usahatani dan juga agar memperoleh pendapatan yang tinggi. Prinsip-prinsip usahatani untuk memperoleh keuntungan, adalah :

1. Penentuan perkembangan harga. Keuntungan usahatani tergantung pada harga hasil produksi sesudah produk dihasilkan, bukan waktu tanaman di lapangan atau pada waktu ternak dalam proses penggemukan. Dengan demikian pengetahuan tentang harga faktor produksi yang digunakan dan harga produk yang dihasilkan serta harga produk lain yang dapat mempengaruhi harga produksi yang dihasilkan sangat penting.

2. Kombinasi beberapa cabang usaha. Keuntungan usahatani tidak hanya ditentukan oleh tingginya pendapatan dari suatu cabang produksi tertentu saja. Keuntungan akhir dari satu tahun kerja yang bersih ditentukan oleh semua cabang produksi yang diusahakan. Untuk itu pemilihan kombinasi yang tepat diperlukan agar memperoleh keuntungan yang setinggi-tingginya dalam setahun.

3. Pemilihan cabang usaha. Pemilihan cabang usaha merupakan faktor penting misalnya tanaman apa yang ditanam atau ternak apa yang akan diternakkan agar dapat menguntungkan. Karena disesuaikan dengan luas usahatani, tipe usahatani, produktivitas tanah, persediaan tenaga kerja, biaya mendirikan cabang usaha, keadaan harga diwaktu cabang usaha itu menghasilkan, fasilitas pemasaran.

4. Penentuan cara berproduksi. Agar keuntungan diperoleh maka perlu ditentukan, antara lain, jumlah pupuk yang akan digunakan per hektar, jenis pupuk yang akan digunakan, jarak tanam, cara bercocok tanam yang lebih baik, cara panen yang ekonomis. Setiap sarana produksi yang akan digunakan harus dibandingkan dengan kemungkinan hasil produksi yang akan diperoleh.

5. Pembelian sarana produksi yang diperlukan. Usahatani yang komersil biasanya memerlukan tiga perempat dari jumlah sarana produksi yang berasal dari luar usahataninya. Sehingga perlu pengetahuan tentang jumlah dan cara pembelian sarana, peralatan dan bahan lainnya, mengingat modal dan tenaga kerja yang terbatas, agar uang yang ada dapat digunakan secara tepat. Antara lain harus memilih antara membeli makanan, pupuk atau membeli peralatan.

6. Pemasaran hasil usahatani. Besar penerimaan usahatani ditentukan oleh harga dari hasil yang diproduksi. Harga yang optimal dipengaruhi, antara lain, oleh: waktu penjualan, tempat penjualan, cara penjualan, kualitas produksi, cara pengepakan yang efisien dan alat angkutan yang digunakan.

7. Pembiayaan usahatani. Biaya yang diperlukan untuk jangka panjang meliputi biaya pengembangan dan perluasan usaha. Sedangkan biaya jangka pendek meliputi biaya tanam, biaya perbaikan alat, biaya hidup selama menunggu panen. 
8. Pengelolaan modal dan pendapatan. Kurangnya modal merupakan pembatas untuk berusahatani lebih komersil. Pendapatan usahatani sebagian besar untuk konsumsi keluarga. Dengan demikian perlu sikap yang hati-hati dalam melakukan investasi.

Berdasarkan 8 prinsip di atas maka untuk mencapai keputusan yang menguntungkan diperlukan langkah-langkah: memahami permasalahan yang dihadapi, menganalisa dan mengambil keputusan.

Selanjutnya menyangkut keadilan gender perlu kita soroti terlebih dahulu menyangkut perbedaan gender. Perbedaan gender sepanjang tidak menimbulkan ketidak adilan gender sesungguhnya tidaklah menjadi masalah. Namun, pada kenyataannya perbedaan gender telah menimbulkan berbagai ketidak adilan gender, baik bagi kaum laki-laki dan terutama bagi kaum perempuan. Hal ini terjadi pula dalam usahatani.

Ketidakadilan gender terwujud dalam berbagai bentuk yang memiliki saling keterkaitan, yaitu: marginalisasi atau proses pemiskinan ekonomi, subordinasi atau anggapan tidak penting dalam keputusan politik, pembentukan stereotipe atau pelabelan negatif, kekerasan (violence), beban kerja lebih panjang dan lebih banyak (burden) serta sosialisasi ideologi nilai peran gender.

Dalam kegiatan usahatani keadilan gender terutama tampak dengan terjadinya marginalisasi dan stereotipe.

Marginalisasi, antar lain, terjadi dalam program swasembada pangan atau revolusi hijau (green revolution) secara ekonomis telah menyingkirkan kaum perempuan dari pekerjaannya sehingga memiskinkan mereka. Penggunaan sabit menggantikan ani-ani yang digunakan wanita yang menyebabkan banyak kaum perempuan miskin di desa termarginalisasi, yakni semakin miskin dan tersingkir karena tidak mendapatkan pekerjaan di sawah pada musim panen. Berarti program revolusi hijau dirancang belum mempertimbangkan aspek gender.

Stereotipe nampak dalam pemberian upah yang berbeda antara tenaga kerja laki-laki dan perempuan untuk jenis pekerjaan yang sama. Karena anggapan perempuan lebih lemah dan karena anggapan bahwa pendapatan perempuan hanya merupakan pendapatan tambahan saja.

\section{RATIO KEUNTUNGAN USAHATANI YANG BERKEADILAN GENDER ( IKUBG )}

Untuk mendapatkan gambaran suatu usahatani yang menguntungkan bagi kaum laki-laki maupun perempuan berada pada tingkat mana, dan agar dapat membandingkan antar usahatani maka di usulkan penggunaan ratio keuntungan usahatani yang berkeadilan gender (RKUBG) atau Benefit Gender Ratio (BG Ratio).

\section{BG Ratio = Konstanta keadilan gender (KKG) $x$ Benefit Cost ratio $(\mathrm{B} / \mathrm{C})$}

$\mathrm{KKG}=$ jumlah skor bersama setara antara pria dan wanita untuk kegiatan yang berhubungan dengan:

- Tanah (status kepemilikan atau pengelolaan tanah)

- Upah kerja (jumlah upah, kesetaraan pekerja laki-laki dan perempuan yang akan diajak kerja)

- Modal (keputusan tentang modal)

- Manajemen (siapa yang membuat keputusan untuk pemasaran)

$\mathrm{B} / \mathrm{C}=$ penerima - biaya/total biaya $\times 100$ persen

Semakin besar nilai BJ Ratio semakin adil gender sedangkan semakin kecil nilai BJ Ratio semakin tidak adil gender. 


\section{TELADAN KASUS (HIPOTESIS):}

Sebuah usahatani di Desa A ternyata tanah diperoleh melalui pembelian yang dilakukan suami-isteri yang telah dibuat sertifikat atas nama suami dan istri. Dalam menentukan tenaga kerja sebagai pemilik tanah diajak baik pria maupun wanita dalam penyiapan lahan, pembibitan, penanaman, penyiangan, pemupukan, pemberantasan hama dan panen. Pengelolaan modal usahatani diputuskan suami saja tanpa mengikutsertakan istri demikian pula dalam keputusan pemasaran. Biaya usahatani yang dikeluarakan sebesar Rp. 1.000.000,- per hektar per musim. Hasil penjualan sebesar Rp. 1.500.000,-

\section{DIAGNOSIS SEBAGAI BERIKUT :}

Penghitungan nilai $\mathrm{KKG}=$

\begin{tabular}{|c|c|c|c|c|}
\hline \multirow[t]{2}{*}{ No } & \multirow[t]{2}{*}{ Uraian } & \multirow[t]{2}{*}{$\begin{array}{c}\text { Nilai } \\
\text { Kegiatan }\end{array}$} & \multicolumn{2}{|c|}{$\begin{array}{c}\text { Pria } \\
\text { Wanita } \\
\text { Setara }\end{array}$} \\
\hline & & & $\mathrm{Ya}$ & Tidak \\
\hline 1 & Tanah & 1 & 1 & 0 \\
\hline \multirow[t]{4}{*}{2} & Tenaga & & & \\
\hline & kerja & 1 & 0 & 1 \\
\hline & A. Upah & 1 & 1 & 0 \\
\hline & $\begin{array}{l}\text { B. Yang } \\
\text { diajak }\end{array}$ & & & \\
\hline 3 & Modal & 1 & 0 & 1 \\
\hline \multirow[t]{2}{*}{4} & Manajemen & 1 & 1 & 0 \\
\hline & Jumlah & 5 & 3 & 2 \\
\hline
\end{tabular}

Penghitungan nilai BC Ratio :

$\mathrm{B} / \mathrm{C}=\{\operatorname{Rp}(1500000-1000000)\} / 1000$ $000 \times 100 \%=50 \%$

Penghitungan BG Ratio :

BG Ratio $=3 / 5 \times 50 \%=30 \%$

Nilai Batas Minimum yang harus di capai KKG dan BC ratio:
Nilai batas minimum KKG:

Bila:

$\mathrm{KKG}=1$ berarti kesetaraan tercapai sepenuhnya $\mathrm{KKG}=0,5$ berarti cukup setara

$\mathrm{KKG}=0$ berarti kesetaraan tidak tercapai maka batas minimum

$\mathrm{KKG}$ yang harus di capai $=0,5$

Nilai batas minimum BC ratio, yaitu:

nilai $\mathrm{BC}$ ratio $>0$ dan lebih besar dari tingkat bunga yang berlaku per musim di akhir musim.

Bila tingkat bunga bank yang berlaku $=12$ persen per tahun maka batas minimum BC ratio yang harus dicapai untuk tanaman semusim yang berusia 4 bulan $=12$ persen dibagi $3=4$ persen

BJ Ratio minimum yang harus dicapai $=0,5$ $x 4$ persen $=0.20$ persen

\section{Kesimpulan Diagnosis :}

Dengan demikian usahatani ini dapat dikatakan menguntungkan dan berkeadilan gender karena nilainya di atas 0,20 persen, yaitu $30 \%$.

\section{DAFTAR PUSTAKA}

Boserup, Ester. 1984. Peranan Wanita dalam Perkembangan Ekonomi. Yayasan Obor Indonesia, Jakarta .

Bhastoni, K., \& Yuliati, Y. 2016. Peran Wanita Tani di Atas Usia Produktif dalam Usahatani Sayuran Organik Terhadap Pendapatan Rumah Tangga Di Desa Sumberejo Kecamatan Batu. Habitat, 26(2), 119-129.

Fakih, Mansour. 1996. Analisis Gender dan Transformasi Sosial. Pustaka Pelajar, Yogyakarta. 
Oei-Gardiner, Mayling., Mildred Wagemann, Evelyn Suleeman, Sulastri. 1996. Perempuan Indonesia : Dulu dan Kini. Penerbit PT Gramedia Pustaka Utama, Jakarta.

Meiranti, L. 2016. Dinamika Relasi Gender Dalam Rumah Tangga Petani Di Desa Cipelang, Kecamatan Cijeruk, Kabupaten Bogor. Skripsi Sarjana Komunikasi dan Pengembangan Masyarakat pada Departemen Sains Komunikasi dan Pengembangan Masyarakat. Institut Pertanian Bogor, Bogor. http://repository.ipb.ac.id/ jspui/bitstream/ 123456789/81937/ 1/I16lme.pdf

Notoatmojo, B. 2001. Peranan Gender Dalam Usaha Tani Di Kawasan Indonesia Bagian Timur. Journal The Winners, Vol. 2 No. 2, September 2001: 116-129.
Rosmawati, R., Rianda, L., \& Taridala, S. A. A. (2016). Peran Gender Dalam Rumah Tangga Petani Rumput Laut Di Kabupaten Buton Utara Sulawesi Tenggara. Jurnal Bisnis Perikanan, 2(1).

Soeharjo, A. dan Dahlan Patong. 1973. Sendisendi Pokok Ilmu Usahatani. Institut Pertanian Bobor, Bogor.

Taridala, S. A. A. 2010. Analisis Peran Gender Dalam Pencapaian Ketahanan Pangan Rumahtangga Petani Di Kabupaten Konawe Selatan provinsi Sulawesi Tenggara. Disertasi . Sekolah Pascasarjana. Institut Pertanian Bogor. http://repository.ipb.ac.id/jspui/bitstrea m/123456789/55079/1/2010saa.pdf 